\title{
Financial Literacy among Working Young in Urban India
}

\author{
Sobhesh Kumar Agarwalla \\ Samir K. Barua \\ Joshy Jacob \\ Jayanth R. Varma
}

W.P. No. 2013-10-02

October 2013

The main objective of the Working Paper series of IIMA is to help faculty members, research staff, and doctoral students to speedily share their research findings with professional colleagues and to test out their research findings at the pre-publication stage.

\section{INDIAN INSTITUTE OF MANAGEMENT \\ AHMEDABAD - 380015 \\ INDIA}




\title{
FINANCIAL LITERACY AMONG WORKING YOUNG IN URBAN INDIA
}

\author{
Sobhesh Kumar Agarwalla \\ Samir K. Barua \\ Joshy Jacob \\ Jayanth R. Varma ${ }^{1}$
}

\begin{abstract}
The paper reports investigation of a study on the influence of various socio-demographic factors on different dimensions of financial literacy among the working young in urban India. While the influence of several factors such as gender, education and income is similar to what has been reported in other contexts, a few factors specific to India, such as joint-family and consultative decision making process are found to significantly influence financial literacy. The study also investigates the relationship between the dimensions of financial literacy. Adding to the growing empirical understanding of financial literacy across countries, the study provides an analytical basis for enunciating policy for enhancing financial literacy of youth in India.
\end{abstract}

Keywords: Financial Literacy, Financial Knowledge, Financial Behavior, Financial Attitude, Youth, India

JEL classifications: D91, D140

\footnotetext{
${ }^{1}$ We gratefully acknowledge Citi Foundation for their financial support.

All the authors are faculty members at the Indian Institute of Management Ahmedabad, Vastrapur, Ahmedabad, Gujarat, India - 380015. Email:sobhesh@iimahd.ernet.in (Corresponding Author, Address: Wing 7E, IIM Ahmedabad, Vastrapur, Ahmedabad, Gujarat, India 380015; Phone No. +91.79.66324865), skbarua@iimahd.ernet.in, joshyjacob@iimahd.ernet.in, and jrvarma@iimahd.ernet.in.
} 


\section{Introduction}

The role played by governments and employers in managing investments on behalf of individuals has shrunk significantly in the recent past as a result of changes in the social support structures across the world. This has increased individuals' responsibility in managing their own finances and securing their financial future. In an environment where the range and the complexity of financial products continue to increase, it is imperative that individuals develop nuanced understanding of the world of finance to be able to make choices that are most appropriate to their financial goals and needs.

Research from around the world reports inadequate financial literacy which raises serious concerns about the ability of individuals to secure their financial well-being. There is evidence that individuals under-save, fail to invest wisely and are often indebted (Mitchell 2011, Poterba et al. 2007). Such behaviour is also evident among youth, across nations. For instance, Reed and Cochrane who have been reporting on student indebtedness in the US for the last several years, in their latest report observe that about two-thirds of students who graduated from college in 2011 were heavily indebted due to education loans and credit card borrowings (Reed and Cochrane 2012). The high unemployment rate due to the on-going economic downturn is resulting in high delinquency rate among these young borrowers.

The findings of poor financial literacy and financial outcomes have prompted a serious review of existing financial education programs and launch of new programs. Deposing before a congressional hearing committee in April 2011, Ben Bernanke highlighted the need for continual updating of financial literacy across all age groups because of the dynamic nature of financial products and services as well as the changing needs and circumstances of individuals with time (Bernanke 2011). He observed that exposing young people to financial concepts is particularly important as they are vulnerable to the temptations of taking excessive debt. He highlighted the efforts being made by the Federal 
Reserve Board to enhance financial literacy of individuals. Recognizing the need for financial literacy programs inside and outside schools and providing guidance and support to targeted groups who are most at risk, Australian Securities and Investment Commission is reviewing the National Financial Literacy Strategy framed in $2011^{1}$ to set the agenda for the future (ASIC 2013). New Zealand launched its National Strategy for Financial Literacy in 2008 and constituted an advisory committee that is supposed to update on the action plans on a half-yearly basis ${ }^{2}$. The strategy is attempting to integrate the initiatives such as the New Zealand Financial Literacy Program developed by Enterprise New Zealand Trust to improve financial decision making skills of youth. The effort to improve financial literacy in UK is led by Financial Services Authority of UK. It has called for joint action by financial industry and consumer activists to improve the level of financial literacy in UK (FSA 2006). The effort to enhance financial literacy in India over the last decade has also been given an impetus by the country's central banker, the Reserve Bank of India that has mandated that banks take the initiative to enhance financial inclusion and financial literacy in the country. A draft national strategy for financial education was prepared and released by RBI in July 2012 (RBI 2012). The strategy includes observations on not only the role of the banks but also the need for financial education in schools.

Financial literacy is of particular relevance to emerging economies. As these economies endeavour to improve the financial situation of their citizens by achieving higher economic growth rates, enhancement of financial literacy would help improve the financial well-being of their people even further through sound financial decision making.

In addition to providing a comparative picture of the situation of the working young in urban India with the situation of similar groups in several other countries, this is perhaps the first study that has rigorously attempted to unravel the determinants of financial literacy in the context of India. The study is particularly relevant for India given that it is a

\footnotetext{
${ }^{1}$ ASIC (2011)

${ }^{2}$ National Strategy for Financial Literacy, 2012. Commission for Financial Literacy and Retirement Income. Downloaded from http://www.cflri.org.nz/sites/default/files/docs/FL-NS-National\%20Strategy-2012-Aug.pdf on 25 August, 2013
} 
young nation with more than $65 \%{ }^{3}$ of its population below the age of 35 and which is rapidly urbanizing. The study investigates the socio-demographic variables that influence their financial attitude, financial behavior and financial knowledge of the working young in urban India. The study investigates the influence of contextual variables that are unique to India on financial literacy and provides useful insights for policy making. The study also examines the relationship among the three dimensions of financial literacy using a new methodology that is free from the influence of the attributes of the respondents. The results of such an examination are surprising and instructive.

The paper is organized as follows. Section 2 provides a brief review of relevant literature on financial literacy. Section 3 describes the sample size and sample descriptives. Section 4 describes the methodology used for measuring the effects of various socio-demographic variables on financial knowledge, financial behavior and financial attitude. Section 5 explains the results from the regression model and Section 6 concludes.

\section{Literature Review}

While several widely used definitions of financial literacy exist, all of them generally imply the ability of individuals to obtain, understand and evaluate information required to make decisions to secure their financial future as best as possible. After analyzing a host of papers on the subject, Huston (2010) proposed that financial literacy must also include application of financial knowledge; the argument being that absent demonstrated ability to apply financial knowledge, an individual cannot be regarded as being financially literate. After due consideration of different views and the feasibility of using the definition for research, the OECD definition of financial literacy was adopted for the study, which defines it as, "A combination of awareness, knowledge, skill, attitude and behavior

\footnotetext{
${ }^{3}$ As of 2011. Source: http://www.censusindia.gov.in/2011census/Age_level_data/Age_level_data. html
} 
necessary to make sound financial decisions and ultimately achieve individual financial wellbeing." (OECD INFE, 2011). Since the OECD definition has been used for surveys on financial literacy across several countries, use of that definition provides the possibility of benchmarking the results in the Indian context against the results for other countries.

Research across the world has focused attention on documenting the extent of financial literacy among different categories of people as well as attempted to discover the sociodemographic variables that appear to have significant influence on financial literacy so as to be able to develop appropriate interventions to enhance financial literacy. Research has attempted to provide analytical insights to shape policy interventions. Evidence from around the world presents alarming and widespread deficiency in financial literacy. The evidence has led to the launch of financial literacy programs in many countries. While the programs vary widely in their scope and approach across countries, the underlying objectives are to improve the financial attitude, the financial behavior and the financial knowledge of individuals to enable them and their families to make choices that improve their financial well-being. Xu and Zia (2012) summarize the findings of various financial literacy studies conducted across the world.

Implicitly defining financial knowledge as financial literacy, Lusardi et al. (2010) investigated financial literacy among the young in the US using data collected through the National Longitudinal Survey of Youth in 2007-08. The research questions they sought answers to related to preparedness of the young to make sound financial decisions, determinants of financial literacy among the young and policy initiatives needed to improve financial literacy of the young. They found that the level of financial literacy among the young is low. This inference is consistent with findings across the world that despite concerted efforts to improve financial literacy, it continues to be inadequate among the young. They found that the level of financial literacy was significantly influenced by socio-demographic attributes and the family financial situation and sophistication. Specifically, they found significant difference between women and men, with women 
showing lower level of financial literacy. This confirmed similar conclusion reported in Lusardi and Mitchell (2008), Lusardi and Tufano (2009), Agnew and Szykman (2005) and studies in other countries such as those by Smith and Stewart (2009), Lusardi and Mitchell (2007), Van Rooij et al. (2007). This conclusion is in conformity with conclusion reached by Mandell (2008) among school students and by Lusardi and Mitchell (2007), Lusardi and Tufano (2009) among other age groups. The study found significant positive influence of education, especially college education on financial literacy. The study found that mother's education had a significant positive influence on financial literacy. The family financial situation and sophistication also had significant positive influence on financial literacy. This conclusion is in conformity with research by Chiteji and Stafford (1999), Li (2011). The policy prescriptions arising from the study are quite apparent.

Several studies have attempted to examine the level of financial literacy in India. Most of them report that the level of financial literacy in India is poor. For instance, the VISA (2012) study ranked India at the 23rd position among the 28 countries surveyed. Adopting the questionnaire developed by the Organisation for Economic Co-operation and Development (OECD) to facilitate international benchmarking ${ }^{4}$, this study attempted to further the knowledge and understanding of financial literacy is India. Compared to some of the other studies, the OECD approach is more comprehensive as it attempts to measure the influence of a range of explanatory variables on the three dimensions of financial literacy, namely, financial attitude, financial behavior and financial knowledge.

While there are a few variables that appear to have similar influence across different nationalities, what is interesting is that there generally are contextual variables that influence financial literacy. Discovering these would be important for framing country specific intervention strategies.

\footnotetext{
${ }^{4}$ Written consent was received from the OECD, for using the OECD-INFE Core Questionnaire and Guidance Notes, on April 2 , 2012. The two questionnaires which are part of the OCED financial literacy survey approach are: OECD-INFE (2011) and OECD-INFE (2012)
} 


\section{The Sample}

The study was focused on the working youth in urban India. Given the wide socio-economic diversity, the sample was drawn from six major cities spread across the country. Data was collected through a survey in May, 2012 by engaging the services of an established market research agency. The attributes on which data was collected were gender, age, level of education, marital status, family income, financial decision making process and budgeting of expenditure. A distinctive feature of Indian society is that even after turning adult and getting married a male may live (with his spouse and children) under the same roof with his parents and brothers and their families - in what is known as a 'joint family' 5 Since this attribute could have a significant influence on the response variables namely financial knowledge, financial behavior and financial attitude, under investigation, data was also collected on whether a respondent lived in a nuclear or a joint family. Though the target sample size was 1,000 , after preliminary analysis of the data, the usable sample, with information on all dimensions and variables, reduced to 754 . The detailed distribution of the sample across various attributes is presented in Table 1. In addition to information on the attributes, the respondents were required to answers questions pertaining to their financial knowledge, financial behavior and financial attitude.

The level of financial knowledge was measured using a set of eight questions to capture their basic numeracy and understanding of computation of simple and compound interest (time value of money), relationship between inflation and return, inflation and prices, risk and return, and the role of diversification in risk reduction. The financial knowledge scoring adopted by the study followed the approach recommended by the OECD and used by Atkinson and Messy (2012) for measuring financial literacy across 14 countries. Each correct answer was given a score of one. Respondents with score of 6 and above were categorized as individuals possessing high financial knowledge; respondents

\footnotetext{
${ }^{5}$ Chkravorty and Singh (1991) provides a more comprehensive definition of 'Joint Family'.
} 
with scores of 4 and 5 were categorized as individuals with average financial knowledge; the rest were categorized as possessing poor financial knowledge.

The survey attempted to unravel the financial behavior of the respondents by collecting information on the way respondents dealt with money in their daily lives. We adopted the instrument used by the OECD study referred to earlier. A total of eight items were employed to capture the important dimensions that included assessment of affordability of products and expenditures, behavior relating to timely payment of bills, planning and monitoring of household budget, efforts made to evaluate financial products and active saving habits and borrowing propensities. The response to each question was given a score of one if it indicated desirable financial behavior; the score was otherwise zero. Respondents scoring 6 and above were categorized as those demonstrating positive financial behavior; respondents with scores of 4 and 5 were classified as those demonstrating average financial behavior; the rest were categorized as demonstrating indifferent financial behavior.

It may be argued that attitude towards money and finance would affect the behavior towards savings, borrowings and risk-taking of an individual. Based on this argument, the OECD has developed a scale to measure the financial attitude of individuals. The survey measured the financial attitude of the respondents using three items recommended by the OECD to capture the respondent's extent of belief in planning, propensity to save and propensity to consume. The responses were measured using a scale from 1-5, with 5 indicating the highest positive financial attitude. Respondents with an average score of 3 or above across the three items were categorized as those with positive financial attitude; respondents with score of 2 or less were categorized as possessing indifferent financial attitude; the rest were categorized as possessing average financial attitude.

The detailed distributions for the sample on these three dimensions are presented in Table 2. 


\section{The Methodology}

The influence of socio-demographic variables on the three response variables namely, financial knowledge, financial behavior and financial attitude was separately analyzed using ordered multinomial logistic regression. The socio-demographic variables considered were family income, education, marital status, gender, financial decision making process, family composition and financial budgeting. Since all the variables were categorical, dummy variables were used to describe the profile of each respondent. The profile for the base case was: male, unmarried, graduate, who lived on his own, consulted others before taking financial decisions, planned his finances, was member of a family with income of less than INR 20,000 per month and belonged to the lowest category of the response variable. Since the response variables were measured at three levels, the output of the ordered logistic regression would provide an assessment of the influence of the socio-demographic variables on two pairs of comparisons, one involving the lowest and the next levels of response and the other involving the lowest and highest levels of response. The odds ratios for the variables with statistically significant coefficients will provide an assessment of the nature of influence of the variables on the response variable. An odds ratio of greater than one would imply that the variable increases the chance of a desirable response, while an odds ratio of less than one would imply the variable decreases the chance of a desirable response.

It is likely that the different dimensions of the financial literacy could be related to each other. For instance, high financial knowledge could influence both the financial behaviour and attitude. Alternatively, poor financial attitude could lead to less desirable behaviour. These relationships need to be examined to gain insights into how the different dimensions of financial literacy influence each other. The literature available has consistently examined such relationships between the three dimensions through the intermediate variables such as income and education. In addition, financial knowledge by most researchers on the 
issue has been measured by financial information rather than understanding of concepts in finance.

The study uses an entirely new approach for exploring the linkages between the three dimensions of financial literacy. The methodology proposed assesses the inter-linkages after removing the possible influence of respondent specific values of socio-demographic variables. The participants were ranked separately according to their scores on Financial Knowledge, Financial Behavior and Financial Attitude. The Spearman's Rank Correlation Coefficient was then computed for the three distinct pairs of dimensions to explore the nature of relationship between the three dimensions.

It is indeed true that functionally, financial knowledge, behavior and attitude are three independent dimensions representing three different aspects of financial literacy. Summation of the scores on the three dimensions to measure an individual's score on financial literacy would be conceptually questionable since two persons with identical scores for financial literacy may be very different from each other in terms of the underlying dimensions. And yet, that is how the OECD study ${ }^{6}$ has compared the level of financial literacy across several countries. Since the OECD study is one of the most comprehensive comparative studies on financial literacy of several countries, despite reservations about the methodology, this study too used a composite score of financial literacy and compared the same with the scores reported by the OECD for several other countries.

\section{$5 \quad$ Results and Discussions}

\subsection{Financial Knowledge}

About $24 \%$ of the respondents exhibited high financial knowledge. This was a relatively low score compared to the OECD survey across the 13 countries, where on an average,

\footnotetext{
${ }^{6}$ This follows the approach adopted by the OECD in their financial literacy survey
} 
more than half of the respondents scored high on financial knowledge (Atkinson and Messy 2012). The lowest scoring country in the OCED survey, South Africa, had about one-third respondents with high financial knowledge. Rest of the countries in the OCED survey had more than $40 \%$ of respondents with high financial knowledge. The performance on different dimensions suggested lack of understanding of the basic principles related to money in everyday life. Nearly one-third of the respondents were unable to perform the simple numerical task involving division. Further, meaningful understanding of inflation was not widespread. Only about $19 \%$ of the respondents understood the impact of inflation on the rate of return. Even on the other dimensions of financial knowledge, the scores were relatively low compared to the countries surveyed by the OECD.

The output of detailed analysis of the influence of the explanatory variables using multinomial logistic regression is presented in Table 3. Family income, gender and living in joint family were three variables that showed statistically significant influence in both the sets of comparisons. Family income showed significant positive influence on financial knowledge, with the influence increasing with rise in family income. The odd ratios at the highest level of family income were about 4 and 17 when low financial knowledge was compared with average and high financial knowledge respectively. Gender showed a significant influence on the level of financial knowledge with women showing significantly lower levels of financial knowledge compared to men. The odds ratios for female were about one-half and one-third when low financial knowledge was compared with average and high financial knowledge respectively. Living in joint family negatively impacted the level of financial knowledge with the odds ratios declining to about one-third in both the comparisons. The other variables showed influence at varying levels of statistical significance in one of the two comparisons. While post-graduation and marriage increased, absence of budgeting decreased the chance of average compared to low financial knowledge. Financial decision making by self without consultation decreased the chance of high compared to low financial knowledge. 


\subsection{Financial Behavior}

A majority of the respondents engaged in desirable financial behavior when dealing with personal money and household finance. Based on the financial behavior score, about $68 \%$ of the employed were classified as possessing positive financial behaviour. This was comparable with the financial behaviour reported for Germany, Norway, Ireland, Malaysia and Peru by the OECD survey, where about $60 \%$ scored high on financial behaviour (Atkinson and Messy 2012). About $90 \%$ of the responded were found to be strongly inclined to assess the affordability of items. On this dimension, it appeared that respondents in India were not different from those in several other countries surveyed by the OECD. In fact, Indians appeared to be one among the best in their propensity to assess affordability. Similarly, on timeliness of the payment of bills respondents from India had scores that were similar to the scores of respondents from other countries in the OECD survey. The practice of financial goal setting among the respondents too was at par with the practice observed in several other countries included in the OECD survey. About $66 \%$ of the respondents reported that they avoided borrowing by depending on their savings or assets during periods of financial difficulty. All the respondents reported that they had saved some money in the past 12 months and about $87 \%$ of the respondents reported that they had attempted to carefully evaluate the financial products. These high scores of the respondents suggested that the young employed in India are reasonably self disciplined in their dealing of money and household finance. The relatively high level of financial-discipline shown by the respondents could perhaps be due to the relatively low level of per capita income and the absence of general social support systems in India.

The output of detailed analysis of the influence of the explanatory variables using multinomial logistic regression is presented in Table 4. Gender, education, absence of financial planning and family income were four variables that showed statistically significant influence in both the sets of comparisons. Gender showed a significant influence on financial behavior, with women showing significantly inferior financial 
behavior compared to men. The odds ratios were about two-fifth and one-sixth when indifferent financial behavior was compared with average and good financial behavior respectively. Absence of college education as well as absence of budgeting showed a negative influence on desirable financial behavior. The odds ratio for indifferent education level (higher secondary and equivalent) were about one-fourth for both the comparisons. The odds ratios for absence of budgeting were about one-fourth and one-seventh when indifferent financial behavior was compared with average and good financial behavior respectively. A rise in family income from the lowest to the middle level positively influences desirable financial behavior. Financial decision making without consultation increased the chance of improved financial behavior, with the behavior improving one notch from the lowest category of behavior.

\subsection{Financial Attitude}

Close to half of the respondents exhibited a positive attitude towards financial planning and did not show a very high propensity for consumption. This was comparable to the levels observed in the OECD survey in Estonia and United Kingdom (Atkinson and Messy 2012). However, the scores were much lower compared to many other less developed countries in the Eurozone like Czechoslovakia, Hungary and Albania.

The output of detailed analysis of the influence of the explanatory variables using multinomial logistic regression is presented in Table 5. Gender, family income and decision making by self were three variables that showed statistically significant influence in both the sets of comparisons. Unlike effect of gender on financial knowledge and behavior, women showed significantly superior financial attitude compared to men. The odds ratios were about 2 and 4 when indifferent financial attitudes was compared with average and positive financial attitude respectively. While increase in family income increased the chance of positive compared to indifferent financial attitude, increase in family income decreased the chance of improvement in financial attitude to average from 
indifferent. While financial decision making by self decreased the chance of positive compared to indifferent financial attitude, it increased the chance of financial attitude being average compared to indifferent. Living in joint family reduced the chance of positive compared to indifferent financial attitude. Absence of budgeting improved the chance of positive compared to indifferent financial attitude.

\subsection{Financial Knowledge, Behavior and Attitude: Inter-linkages}

The Spearman's rank correlation coefficients for the three pairs of dimensions of financial literacy are presented in Table 6. The correlation between financial knowledge and financial behavior was positive and highly significant. This bears out the belief that adequate financial knowledge would lead to responsible financial behaviour. The correlation between financial knowledge and financial attitude was not different from zero, indicating that empirically they are two independent dimensions. The significant negative correlation between financial behavior and financial attitude defied easy explanation. It would appear that the professed sensible attitude towards money and finance was accompanied with poor financial behavior on the part of respondents. This indicates possible absence of self-control among respondents.

\subsection{Financial Literacy: India versus Other Countries}

The financial literacy score for each respondent was computed by adding the scores in the three underlying dimensions, namely, financial knowledge, behaviour and attitude. The maximum score that was possible for financial literacy was 21 ( 8 for financial behaviour, 8 for financial knowledge, and 5 for financial attitude). The average score for the sample at 13.8 , was within the range of average scores of 12.4 to 15.1 reported by the OECD study for the 13 countries covered in its survey. ${ }^{7}$ India is well ahead of several countries that include

\footnotetext{
${ }^{7}$ The actual average was inflated by multiplying it with $22 / 21$ to match the maximum financial literacy score of the OECD survey
} 
South Africa, Armenia, Poland, Estonia, and Albania. As stated in the earlier sections of the paper, India fares relatively poorly as regards score in financial knowledge.

\section{Conclusion}

Overall, the level of financial literacy among the working young in urban India is similar to the levels that prevail among comparable groups in other countries. The inferences reached by the study on the influence of several socio-demographic variables in the Indian context also confirm inferences reached by studies elsewhere. For example, the influence of family income and gender on various dimensions of financial literacy is similar to the influence recorded in other studies. There are however differences that are worthy of note. Despite the education levels of the respondents in the sample being high (large proportion being graduate and post-graduate), that does not translate into adequate financial literacy. This is likely to be due to absence of inputs relevant to financial literacy in the general education process. This can be easily corrected. Given the emphasis on education in India, it should be possible to enhance the financial literacy of youngsters relatively quickly through inclusion of relevant material on financial literacy in the general education program of schools and colleges. The study demonstrates the importance of contextual variables that may influence financial literacy. The influence of joint-family and the consultative financial decision making process that are variables specific to India confirm the importance of contextual variables. The distinct methodological lesson from the study is that idiosyncratic attributes pertaining to the sociological and the behavioral aspects of the society being studied are important in unravelling the determinants of financial literacy. Any intervention strategy must take into account these sociological and behavioral aspects peculiar to the context. The influence of the contextual variables suggests that the focus of any strategy for improving financial well-being of youngsters in India would have to be broader than just the individual. 
The study also explored the relationships between the three dimensions of financial literacy using a methodology that is free from influence of the attributes of the respondents. While the significant positive relationship between financial knowledge and financial behavior is perhaps to be expected, the significant negative relationship between financial attitude and financial behaviour is surprising. One plausible explanation for the latter result is likely to lie in the concept of locus of control. Despite having sensible attitude towards managing their finances, youngster tend to behave in a profligate manner which therefore gives rise to the observed negative association between attitude and behaviour. 


\section{References}

Agnew, J. R. and Szykman, L. R. (2005). Asset allocation and information overload: The influence of information display, asset choice, and investor experience. The Journal of Behavioral Finance, 6(2):57-70.

ASIC (2011). National financial literacy strategy. Australian Securities \& Investment Commission Report No. 229. Downloaded from http://www.financialliteracy.gov.au/media/218312/ national-financial-literacy-strategy •pdf on 25 August, 2013.

ASIC (2013). Shaping a national financial literacy strategy for 2014 - 16. Australian Securities \& Investment Commission Consultation Paper No. 206. Downloaded from http://www.financialliteracy.gov.au/media/ 424937/shaping_a_national_financial_literacy_strategy_for_ 2014-16_consultation_paper.pdf on 25 August, 2013.

Atkinson, A. and Messy, F.-A. (2012). Measuring financial literacy: Results of the OECD / International Network on Financial Education (INFE) pilot study. OECD Working Papers on Finance, Insurance and Private Pensions No. 15, OECD Publishing. Available at http://dx.doi.org/10.1787/5k9csfs90fr4-en.

Bernanke, B. S. (2011). Statement by Chairman Bernanke on financial literacy. Provided for the record of a hearing held on April 12, 2011 conducted by the Subcommittee on Oversight of Government Management, the Federal Workforce, and the District of Columbia, Committee on Homeland Security and Governmental Affairs, U.S. Senate. Downloaded from http: //www. federalreserve.gov/newsevents / testimony/bernanke20110420a.htm on 25 August, 2013.

Chiteji, N. S. and Stafford, F. P. (1999). Portfolio choices of parents and their children as young adults: Asset accumulation by African-American families. The American Economic Review, 89(2):377-380. 
Chkravorty, C. and Singh, A. K. (1991). Household structures in india. Census of India, Occasional Paper 1.

FSA (2006). Financial capability in the UK: Delivering change. Financial Services Authority, UK. Downloaded from http://www.fsa.gov.uk/pubs/other/ fincap_delivering.pdf on 25 August, 2013.

Huston, S. J. (2010). Measuring financial literacy. Journal of Consumer Affairs, 44(2):296316.

Li, G. (2011). Information sharing and stock market participation: evidence from extended families. Federal Reserve Board. Downloaded from http://works.bepress . com/cgi/viewcontent.cgi?article=1041\&context=geng_li on 25 August, 2013.

Lusardi, A. and Mitchell, O. S. (2007). Financial literacy and retirement preparedness: Evidence and implications for financial education. Business Economics, 42(1):35-44.

Lusardi, A. and Mitchell, O. S. (2008). Planning and financial literacy: How do women fare? National Bureau of Economic Research.

Lusardi, A., Mitchell, O. S., and Curto, V. (2010). Financial literacy among the young. Journal of Consumer Affairs, 44(2):358-380.

Lusardi, A. and Tufano, P. (2009). Debt literacy, financial experiences, and overindebtedness. CFS Working Paper No. 2009/08.

Mandell, L. (2008). Financial education in high school. Overcoming the saving slump: How to increase the effectiveness of financial education and saving programs, pages $257-279$.

Mitchell, O. S. (2011). Managing risks in defined contribution plans: What does the future hold? Growing Old: Paying for Retirement and Institutional Money Management After the Financial Crisis. 
OECD-INFE (2011). Measuring financial literacy: Core questionnaire in measuring financial literacy: Questionnaire and guidance notes for conducting an internationally comparable survey of financial literacy. Paris: OECD. OECD International Network on Financial Education (INFE). Downloaded from http://www. oecd. org/finance/financial-education/49319977.pdf on 10 May, 2012.

OECD-INFE (2012). Supplementary questions: Optional survey questions for the oecd-infe financial literacy core questionnaire. Paris: OECD. OECD International Network on Financial Education (INFE). Downloaded from http://www. oecd. org/dataoecd/43/61/49878153.pdf on 10 May, 2012.

Poterba, J., Venti, S., and Wise, D. A. (2007). The changing landscape of pensions in the united states. Technical report, National Bureau of Economic Research.

RBI (2012). National strategy for financial education. Reserve Bank of India. Downloaded from http://rbidocs.rbi.org.in/rdocs/PublicationReport/Pdfs/ NSFE016072012.pdf on 25 August, 2013.

Reed, M. and Cochrane, D. (2012). Student debt and the class of 2011. The Institute of College Access \& Success.

Smith, B. A. and Stewart, F. (2009). Learning from the experience of organisation for economic co-operation and development countries: Lessons for policy, programs, and evaluations. Overcoming the Saving Slump: How to Increase the Effectiveness of Financial Education and Saving Programs, page 345.

Van Rooij, M., Lusardi, A., and Alessie, R. (2007). Financial literacy and stock market participation. National Bureau of Economic Research.

VISA (2012). Visa's international financial literacy barometer, 2012. Downloaded from http://www.practicalmoneyskills.com/resources/pdfs/FL_ Barometer_Final.pdf on 25 August, 2013. 
Xu, L. and Zia, B. (2012). Financial literacy around the world: an overview of the evidence with practical suggestions for the way forward. World Bank Policy Research Working Paper, (6107). 
Table 1: Distribution of Sample on Socio-demographic Variable

\begin{tabular}{|c|c|c|c|c|}
\hline \multirow{2}{*}{ Variable } & \multirow{2}{*}{ Number } & \multicolumn{3}{|c|}{ Average Score } \\
\hline & & $\begin{array}{r}\text { Financial } \\
\text { Knowledge }\end{array}$ & $\begin{array}{l}\text { Financial } \\
\text { Behavior }\end{array}$ & $\begin{array}{r}\text { Financial } \\
\text { Attitude }\end{array}$ \\
\hline Sample size & 754 & & & \\
\hline \multicolumn{5}{|l|}{ Monthly Family Income in INR* } \\
\hline Up to 20,000 & 237 & 3.51 & 5.87 & 2.45 \\
\hline 20,000 to 50,000 & 395 & 4.37 & 6.2 & 2.95 \\
\hline Above 50,000 & 122 & 4.99 & 6.1 & 3.69 \\
\hline \multicolumn{5}{|l|}{ Educational Level } \\
\hline Post-Graduate & 140 & 4.47 & 6.18 & 2.74 \\
\hline Graduate & 541 & 4.2 & 6.13 & 2.99 \\
\hline HSC/Technical,Vocational Education & 73 & 3.64 & 5.55 & 2.72 \\
\hline \multicolumn{5}{|l|}{ Marital Status } \\
\hline Married & 202 & 4.38 & 6.34 & 3.28 \\
\hline Single & 552 & 4.13 & 5.99 & 2.78 \\
\hline \multicolumn{5}{|l|}{ Gender } \\
\hline Male & 578 & 4.28 & 6.23 & 2.68 \\
\hline Female & 176 & 3.93 & 5.59 & 3.67 \\
\hline \multicolumn{5}{|l|}{ Financial Decision Making } \\
\hline Self & 246 & 3.95 & 5.89 & 2.56 \\
\hline In consultation with others & 508 & 4.32 & 6.17 & 3.08 \\
\hline \multicolumn{5}{|l|}{ Family Type } \\
\hline Nuclear family & 580 & 4.34 & 6.16 & 2.97 \\
\hline Joint Family & 174 & 3.73 & 5.82 & 2.73 \\
\hline \multicolumn{5}{|l|}{ Family Financial Planning (Budget) } \\
\hline Yes & 637 & 4.28 & 6.28 & 2.9 \\
\hline No & 117 & 3.75 & 5.01 & 2.98 \\
\hline
\end{tabular}

*As on August 20, 2013 the exchange rate was INR $62=$ USD 1 
Table 2: Distribution of Sample on Response Variables

Response Variable Number

Financial Knowledge

High Financial Knowledge

$24.3 \%$

Average Financial Knowledge

Low Financial Knowledge

$33.3 \%$

Financial Behavior

Good Financial Behavior

$68.2 \%$

Average Financial Behavior

Indifferent Financial Behavior

$6.7 \%$

Financial Attitude

Positive Financial Attitude

$43.0 \%$

Average Financial Attitude

$22.7 \%$

Indifferent Financial Attitude

$34.3 \%$

Total Number of Respondents 
Table 3: Influence of Socio-demographic Variables on Financial Knowledge

The table contains the estimated coefficients from the ordered multinomial logistic regression with financial knowledge as the dependent variable and various socio-demographic variables as independent variables. The model is described in Section 4. The sample size was 754. ***,** and * denote significance at $1 \%, 5 \%$ and $10 \%$ levels respectively.

\begin{tabular}{lrcr}
\hline Variable & DF & Estimate & Odds Ratio \\
\hline \multicolumn{1}{c}{ Average Financial Knowledge versus Low } & Financial Knowledge \\
& & & \\
Intercept & 1 & 0.2313 & 1 \\
Family Income (>50,000) & 1 & $1.3988^{* * * *}$ & 4.0503 \\
Family Income (20,000-50,000) & 1 & $0.3860^{*}$ & 1.4711 \\
Education (Post-Graduate) & 1 & $0.5179 * *$ & 1.6785 \\
Education (HSC \& Equivalent) & 1 & -0.3855 & \\
Married & 1 & $0.4809 * *$ & 1.6175 \\
Female & 1 & $-0.6234 * * *$ & 0.5361 \\
Decision Making (Self) & 1 & 0.0519 & \\
Joint Family & 1 & $-1.0832 * * *$ & 0.3385 \\
No Family Budget & 1 & $-0.6794 * * *$ & 0.5069 \\
\hline
\end{tabular}

High Financial Knowledge versus Low Financial Knowledge

Intercept

Family Income $(>50,000)$

Family Income (20,000-50,000)

Education (Post-Graduate)

Education (HSC \& Equivalent)

Married

Female

Decision Making (Self)

Joint Family

No Family Budget

$\begin{array}{llr}1 & -0.9134 * * * & 0.4011 \\ 1 & 2.8258^{* * * *} & 16.8746 \\ 1 & 1.5702^{* * * *} & 4.8074 \\ 1 & 0.2608 & \\ 1 & -0.5083 & \\ 1 & 0.2312 & \\ 1 & -1.0249 * * * & 0.3588 \\ 1 & -0.7804 * * * & 0.4582 \\ 1 & -1.1095 * * * & 0.3297 \\ 1 & -0.3241 & \end{array}$


Table 4: Influence of Socio-demographic Variables on Financial Behavior

The table contains the estimated coefficients from the ordered multinomial logistic regression with financial behavior as the dependent variable and various socio-demographic variables as independent variables. The model is described in Section 4. The sample size was 754 . ***, ** and * denote significance at $1 \%, 5 \%$ and $10 \%$ levels respectively.

\begin{tabular}{lrlr}
\hline Variable & DF & Estimate & Odds Ratio \\
\hline \multicolumn{4}{c}{ Average Financial Behavior versus Indifferent Financial Behavior } \\
& \multicolumn{1}{c}{} \\
Intercept & 1 & $1.3807^{* * *}$ & 3.9778 \\
Family Income (>50,000) & 1 & 0.6036 & \\
Family Income (20,000-50,000) & 1 & $0.6951^{*}$ & 2.0039 \\
Education (Post-Graduate) & 1 & 0.3798 & \\
Education (HSC \& Equivalent) & 1 & $-1.3076^{* * *}$ & 0.2705 \\
Married & 1 & -0.0023 & \\
Female & 1 & $-0.9576^{* * *}$ & 0.3838 \\
Decision Making (Self) & 1 & $1.0206^{* * *}$ & 2.7748 \\
Joint Family & 1 & 0.4745 & \\
No Family Budget & 1 & $-1.2427^{* * *}$ & 0.2886 \\
\hline
\end{tabular}

Good Financial Behavior versus Indifferent Financial Behavior

Intercept

Family Income $(>50,000)$

Family Income (20,000-50,000)

Education (Post-Graduate)

Education (HSC \& Equivalent)

Married

Female

Decision Making (Self)

Joint Family

$1 \quad 2.9000 * * * \quad 18.1736$

10.8265

$1 \quad 0.8536^{* *} \quad 2.3482$

$1 \quad 0.2030$

$1 \quad-1.3843^{* * *} \quad 0.2505$

$1 \quad 0.4950$

$1 \quad-1.8036^{* * *} \quad 0.1647$

No Family Budget

0.3571

$-0.2416$

$1-1.8745^{* * * *}$

0.1534 
Table 5: Influence of Socio-demographic Variables on Financial Attitude

The table contains the estimated coefficients from the ordered multinomial logistic regression with financial attitude as the dependent variable and various socio-demographic variables as independent variables. The model is described in Section 4. The sample size was 754 . ***, ** and * denote significance at $1 \%, 5 \%$ and $10 \%$ levels respectively.

\begin{tabular}{lccc}
\hline Variable & DF & Estimate & Odds Ratio \\
\hline \multicolumn{4}{c}{ Average Financial Attitude versus Indifferent Financial Attitude } \\
& & & \\
Intercept & 1 & -0.3311 & 1 \\
Family Income (>50,000) & 1 & -0.3205 & \\
Family Income (20,000-50,000) & 1 & $-0.4182^{*}$ & 0.6582 \\
Education (Post-Graduate) & 1 & $-0.5416^{*}$ & 0.5818 \\
Education (HSC \& Equivalent) & 1 & -0.1875 & \\
Married & 1 & -0.3455 & \\
Female & 1 & $0.6807^{* *}$ & 1.9753 \\
Decision Making (Self) & 1 & $0.5987^{* * *}$ & 1.8197 \\
Joint Family & 1 & -0.3370 & \\
No Family Budget & 1 & 0.4188 & \\
\hline
\end{tabular}

Positive Financial Attitude versus Indifferent Financial Attitude

Intercept

Family Income $(>50,000)$

Family Income (20,000-50,000)

Education (Post-Graduate)

Education (HSC \& Equivalent)

Married

Female

Decision Making (Self)

Joint Family

No Family Budget

$\begin{array}{lr}-0.6360 * * * & 0.5294 \\ 2.4778^{* * *} & 11.9155 \\ 0.5545 * * & 1.741 \\ -0.2194 & \\ -0.2726 & \\ 0.6664 * * * & 1.9473 \\ 1.4464 * * * & 4.2478 \\ -0.7998^{* * *} & 0.4494 \\ -0.6081^{* * *} & 0.5444 \\ 0.7590^{* * *} & 2.1362\end{array}$


Table 6: Spearman's Rank Correlation Coefficient

The table contains the estimated Spearman's rank correlation coefficients between financial knowledge, financial behavior and financial attitude. $* * *, * *$ and $*$ denote significance at $1 \%, 5 \%$ and $10 \%$ levels respectively.

\begin{tabular}{lccr}
\hline & Financial Knowledge & Financial Behavior & Financial Attitude \\
\hline Financial Knowledge & 1.000 & & \\
Financial Behavior & $0.304^{* * *}$ & 1.000 & \\
Financial Attitude & -0.019 & $-0.219^{* * *}$ & 1.000 \\
\hline
\end{tabular}

